Article

\title{
Evaluation of Postharvest Processing of Hazelnut Kernel Oil Extraction Using Uniaxial Pressure and Organic Solvent
}

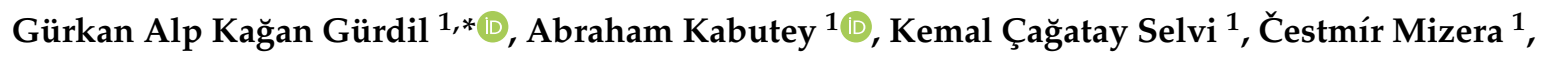 \\ David Herák ${ }^{1}$ and Adéla Fraňková ${ }^{2}$ \\ 1 Department of Mechanical Engineering, Faculty of Engineering, Czech University of Life Sciences Prague, \\ 16521 Prague, Czech Republic; kabutey@tf.czu.cz (A.K.); kcselvi@omu.edu.tr (K.Ç.S.); \\ mizera@tf.czu.cz (Č.M.); herak@tf.czu.cz (D.H.) \\ 2 Department of Food Science, Faculty of Agrobiology, Food and Natural Resources, Czech University of Life \\ Sciences Prague, 16521 Prague, Czech Republic; frankovaa@af.czu.cz \\ * Correspondence: ggurdil@omu.edu.tr; Tel.: +90-362-312-1919
}

Received: 8 July 2020; Accepted: 6 August 2020; Published: 8 August 2020

check for updates

\begin{abstract}
Uniaxial loading and organic solvent are small-scale oil expression methods used to evaluate the mechanical behavior, oil content, and oil efficiency of oil-bearing materials aimed at designing a low-cost mechanical pressing system. Bulk kernels of pressing height $40 \mathrm{~mm}$ were heated from 40 to $60^{\circ} \mathrm{C}$ and compressed at maximum force of $60 \mathrm{kN}$ and speeds from 4 to $8 \mathrm{~mm} / \mathrm{min}$. Relaxation times between 3 and 12 min were applied to assess the kernel oil efficiency. The kernel oil point was identified at deformation levels between 15 and $25 \mathrm{~mm}$ at a speed of $4 \mathrm{~mm} / \mathrm{min}$ using a litmus test. The kernel oil was analyzed for peroxide value and free fatty acid. Kernel oil content was determined by Soxhlet extraction. Increased speed caused a serration effect on the force-deformation curve leading to lower oil yield. Lower and upper oil point forces at $6.21 \pm 0.58$ and $10.61 \pm 0.71 \mathrm{kN}$ were observed to be useful for predicting the pressure for maximum output oil. The peroxide value and free fatty acid content of kernel oil decreased with increasing temperature, indicating its quality usage. The relaxation time of 12 min after compression increased kernel oil efficiency of $15.6 \%$. In designing new presses, there is a need to consider compression and relaxation processes to reduce the residual kernel cake oil.
\end{abstract}

Keywords: bulk hazelnut kernels; mechanical properties; heating temperature; oil efficiency; relaxation process

\section{Introduction}

Hazelnut (Corylus avellana L.) is a fruit consisting of a hard shell with a kernel inside it that is edible [1]. The edible kernel is covered by a removable thin fibrous pellicle, with the internal tissue of the cotyledons consisting of parenchyma cells separated by very small intercellular spaces [2,3]. The tree crop belongs to the family Betulaceae and is grown in the Mediterranean Sea regions, mainly in Turkey, Spain, and Italy [4,5]. Turkey is the main producer and exporter with 420,000 tons/year (contributing around 70\% of the total global production), followed by Italy with 120,572 tons/year, while Spain produces approximately 15,300 tons/year [6-8]. Portugal, France, United States (Oregon and Washington), New Zealand, China, Azerbaijan, Chile, Iran, Georgia, Kirgizstan, Poland, and Croatia are other producing countries [9-11].

Hazelnuts are rich in antioxidant compounds such as tocopherols and polyphenols, unsaturated fatty acids, flavan-3-ols (flavanols) and proanthocyanidins, essential amino acids, dietary fibers, vitamins ( $\mathrm{E}$ and $\mathrm{B})$, and complex and essential minerals $(\mathrm{Ca}, \mathrm{Mg}, \mathrm{P}, \mathrm{K})$, which have a wide range of 
health benefits, including reducing oxidative stress and risk of cancer, stroke, inflammation, and other neurodegenerative diseases [7,12-14]. Hazelnuts are usually used in dairy, bakery, coffee, spreads, confectionery products, and salads due to their nutritious quality and unique flavor [14,15]. In addition, the hazelnut oil is used in cooking, cosmetics, and pharmaceutical industries [16,17]. Hazelnut is primarily composed of oil content (58-65\%), protein (11-16\%), fat content $(60 \%)$, and carbohydrates $(15-18 \%)[18,19]$.

The roasting process is performed to remove the pellicles of kernels, inactivate enzymes, destroy microorganisms, and reduce moisture [11,20]. In addition, roasting is used to improve the sensory features (color, crispy texture, appearance, and flavor) of the product [11,21,22]. Postharvest practices, such as handling, processing, and storage, could affect the biochemical composition and sensory properties of hazelnuts [23-25]. Against this background, knowledge of the physical and mechanical properties of the nuts is useful for the design and development of systems for handling, processing, packaging, storage, and transportation [26-30]. The physical properties of the nuts-mostly the average length, width, thickness, geometric mean diameter, sphericity, unit mass, volume, bulk density, true density, porosity, projected area, terminal velocity, and static and dynamic coefficients of friction - have been studied as a function of moisture content [30-33] where they tend to increase and/or decrease with increases in moisture content. The mechanical properties, on the other hand, include the rupture force, deformation at rupture point, deformation ratio at rupture point, hardness, and energy $[1,34,35]$. According to $[30,36,37]$, the rupture force is the minimum force required to break the sample. The deformation at rupture point is the deformation at loading direction which can be used for the determination of the gap size between the surfaces to compress the fruit or nut for dehulling. Deformation ratio at the rupture point is the axial strain at the rupture point of the sample. Hardness is the ratio of rupture force and deformation at rupture point. The energy for rupture is the energy needed to rupture the sample, which is characterized by the area under the force-deformation curve. It is important to note that moisture content, speed, heating temperature, heating time, pressure, varieties, storage conditions, and vessel diameter thus affect the mechanical properties and force-deformation curves of oil-bearing material [38].

Based on the available literature, there is a lack of information on the postharvest processing of bulk hazelnut kernels in relation to processing factors such as speed, heating temperature, and relaxation time. To aid the design and development of optimal oil processing technology, it is necessary to enhance the knowledge of the uniaxial compression process. The uniaxial compression involves placing the bulk oil-bearing material in a pressing vessel with holes of about $0.5 \mathrm{~mm}$ around the bottom to allow the oil discharge while retaining the seed/kernel cake under a given load and speed using a universal testing machine $[39,40]$. The output data based on the preset pressing variables are usually the force-deformation and relaxation curves, which can further be analyzed to determine the mechanical properties and oil expression efficiency of the oil-bearing material under consideration [36,41,42]. The kernel oil extraction efficiency is determined based on the ratio of kernel oil recovered to that of the kernel oil content determined by Soxhlet extraction. The Soxhlet/solvent extraction technique involves repeated solvent distillation through a solid sample to remove the oil or analyte of interest [43]. Consequently, the study aimed to examine the effects of heating temperature, speed and relaxation time on hazelnut kernel oil processing in uniaxial pressure and to evaluate the chemical properties (peroxide value and free fatty acid) of the kernel oil in relation to heating temperatures.

\section{Materials and Methods}

\subsection{Samples and Moisture Content Determination}

Samples of bulk hazelnut kernels (Figure 1a) were from Ordu province of northeast Turkey, called the East Black Sea region of Turkey $\left(40^{\circ} 58.8^{\prime} \mathrm{N}, 37^{\circ} 52.2^{\prime} \mathrm{E}\right)$. The Cakildak variety was used. The moisture content of $3.46 \pm 0.11 \%$ (w.b.) was determined using the standard procedure where samples were randomly selected and dried at a temperature of $105^{\circ} \mathrm{C}$ for $24 \mathrm{~h}$ [44]. An electronic 
balance (Kern 440-35, Kern \& Sohn GmbH, Balingen, Germany) having an accuracy of $0.01 \mathrm{~g}$ was used to measure the mass $(\mathrm{g})$ of the samples before and after oven drying. To determine the moisture content value, Equation (1) was applied [45].

$$
M C=\left[\left(\frac{m_{b}-m_{a}}{m_{b}}\right) \cdot 100\right]
$$

where $M C$ is the moisture content \% (w.b.) and $m_{a}$ and $m_{b}$ are the masses of the samples before and after oven drying $(\mathrm{g})$.
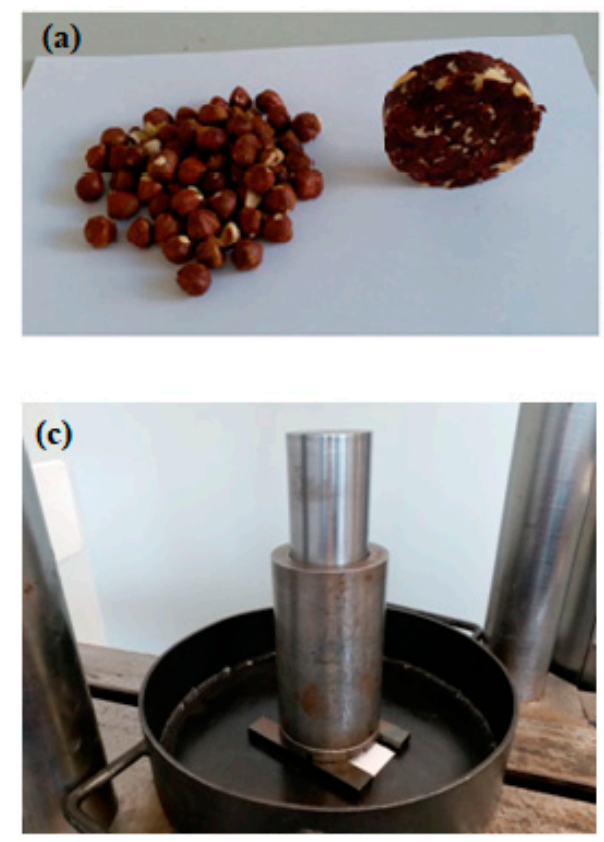
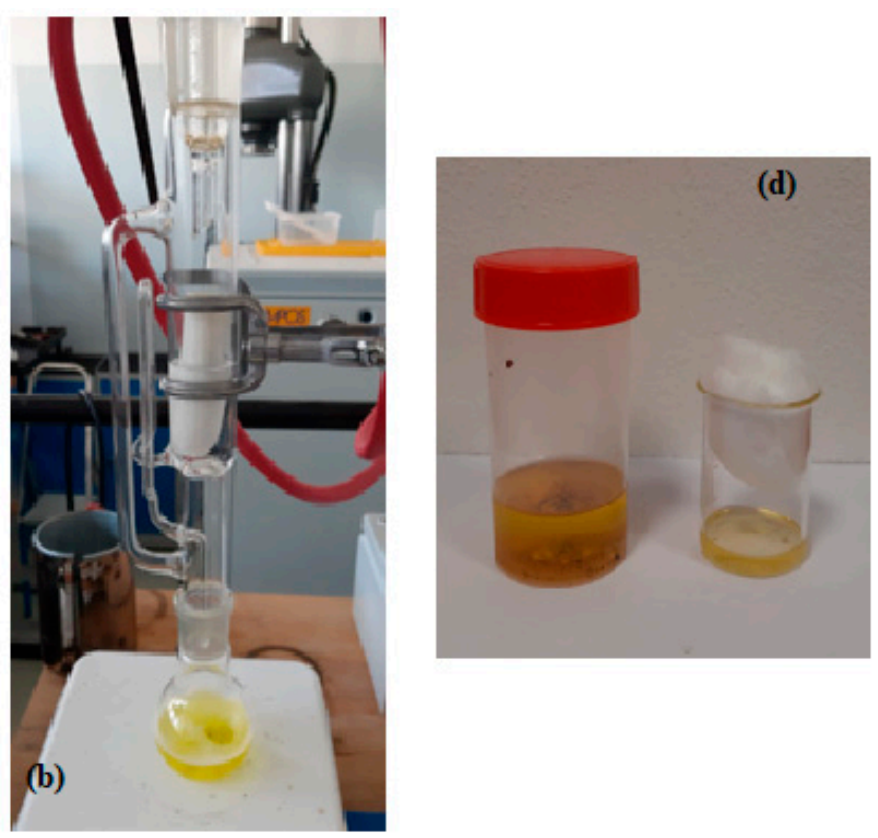

Figure 1. Set up of compression test and Soxhlet extraction: (a) hazelnut kernels and seed cake after compression; (b) Soxhlet extraction setup for kernel oil content determination; (c) a pan holding the pressing vessel with a plunger placed on two separated metal bars with a piece of white paper for oil point identification similar for the compression test; and (d) hazelnut kernel oil from the compression test and Soxhlet extraction (covered with cotton wool).

\subsection{Determination of Percentage Kernel Oil Content}

The percentage kernel oil content (Figure $1 b)$ was determined to be $(64.67 \pm 0.01 \%)$ using the Soxhlet extraction method [46-48]. Based on the procedure, the sample mass of $8 \mathrm{~g}$ was ground and packed into a thimble. The thimble was placed in a Soxhlet extractor attached to a $150 \mathrm{~mL}$ round-bottom flask containing $100 \mathrm{~mL}$ of petroleum ether. The oil extraction process was allowed for $24 \mathrm{~h}$ involving several extraction cycles. The residual water and solvent in the extracted oil were removed by drying at $105^{\circ} \mathrm{C}$ for $5 \mathrm{~h}$. The kernel oil content was calculated based on the dry weight of the sample [45].

\subsection{Heating of Samples}

Samples were heated at temperatures between 40 and $60^{\circ} \mathrm{C}$ using the oven device (MEMMERT $\mathrm{GmbH}+\mathrm{Co}$. KG, Schwabach, Germany) at a heating time of $30 \mathrm{~min}$. The samples laboratory temperature of $25^{\circ} \mathrm{C}$ served as the control.

\subsection{Compression Tests}

The universal compression machine (Tempos, ZDM 50, Czech Republic) together with the pressing vessel of diameter, $D(60 \mathrm{~mm})$ with a plunger (Figure 1c) were used to record the compression and relaxation curves of bulk hazelnut kernels at constant initial pressing height, $H$, of $40 \mathrm{~mm}$ 
(mass $58.31 \pm 0.23 \mathrm{~g}$ and volume $11.31 \cdot 10^{-5} \mathrm{~m}^{3}$ ). The preset load of $60 \mathrm{kN}$ was determined from a preliminary test where the load was initially set at $100 \mathrm{kN}$ and speed $5 \mathrm{~mm} / \mathrm{min}$, which indicated an undulation pattern on the force-deformation curve (ejection of kernel cake through the holes of the pressing vessel). Four separate experiments were performed. The first experiment varied the speed from 4 to $8 \mathrm{~mm} / \mathrm{min}$ at force $60 \mathrm{kN}$ without sample pretreatment. The second experiment considered pretreatment of the samples at temperatures between 40 and $60^{\circ} \mathrm{C}$ for $30 \mathrm{~min}$ and compressed at a force of $60 \mathrm{kN}$ and speed of $4 \mathrm{~mm} / \mathrm{min}$. The third experiment varied the relaxation time from 0 to $12 \mathrm{~min}$ for the samples with a heating temperature of $60^{\circ} \mathrm{C}$, speed of $4 \mathrm{~mm} / \mathrm{min}$, and force of $60 \mathrm{kN}$ to determine maximum oil output. The speed and temperature values were selected based on the results of the preliminary study. The fourth experiment determined the first leakage of the oil (oil point) of the samples before and after pretreatment based on the litmus test procedure [39]. For identifying the lower and upper oil points with the corresponding strain, force, and energy values, the sample deformation levels between 15 and $25 \mathrm{~mm}$ were examined at a speed of $4 \mathrm{~mm} / \mathrm{min}$.

\subsection{Determination of Peroxide Value (PV) and Free Fatty Acid (FFA)}

The hazelnut kernel oil obtained from the compression test (Figure 1d) was evaluated based on peroxide value and free fatty acid. For peroxide value determination, an oil sample of mass of $5 \mathrm{~g}$ was measured into a volumetric flask and dissolved in $30 \mathrm{~mL}$ of a chloroform and glacial acetic acid mixture of ratio 2:3. Saturated potassium iodine $(\mathrm{KI}), 1 \mathrm{~mL}$, was added to the solution and left in a dark place for $5 \mathrm{~min}$. Distilled water $(40 \mathrm{~mL})$ was added and the solution was titrated with $0.1 \mathrm{M} \mathrm{Na}_{2} \mathrm{~S}_{2} \mathrm{O}_{3}$ until the yellow color ceased to be visible. Subsequently, $1 \mathrm{~mL}$ of $1 \%$ starch was added, and the solution was titrated with $\mathrm{Na}_{2} \mathrm{~S}_{2} \mathrm{O}_{3}$ until complete discoloration. For FFA determination, $5 \mathrm{~g}$ of the oil sample was measured into a titration flask, then a $100 \mathrm{~mL}$ of neutralized ethanol (warmed up to $60-65{ }^{\circ} \mathrm{C}$ ) and $2 \mathrm{~mL}$ of $1 \%$ phenolphthalein were added. Titration was performed directly with ethanolic $\mathrm{KOH}$ $(0.1 \mathrm{~g} / \mathrm{mol})$ until the color was light pink. Peroxide value was expressed as ( $\mu \mathrm{g} / \mathrm{g}$ of active oxygen) and free fatty acid was expressed as (mg KOH/g) [1,48,49].

\subsection{Compression Tests Calculated Parameters}

The deformation values were obtained directly from the compression tests. The oil yield (\%) and oil expression efficiency (\%) were calculated according to Equations (2) and (3), as given by [50,51].

$$
\text { OY }=\left[\left(\frac{m_{0}}{m_{s}}\right) \cdot 100\right]
$$

where $O Y$ is the oil yield (\%), $m_{0}$ is the mass of oil obtained as the difference of mass of seed cake and initial mass of the sample $m_{s}(\mathrm{~g})$.

$$
O E E=\left[\left(\frac{O Y}{O_{s}}\right) \cdot 100\right]
$$

where $O E E$ is the oil expression efficiency $(\%)$ and $O_{s}$ is the percentage of oil content $(\%)$. The energy (kJ) was calculated based on the area under the force-deformation curve, which is given by Equation $(4)[52,53]$.

$$
E=\sum_{n=0}^{n=i-1}\left[\left(\frac{F_{n+1}+F_{n}}{2}\right) \cdot\left(x_{n+1}-x_{n}\right)\right]
$$

where $E$ is the deformation energy $(\mathrm{kJ}), F_{n+1}+F_{n}$ and $x_{n+1}-x_{n}$ are the compressive force $(\mathrm{kN})$ and deformation $(\mathrm{mm}), n$ is the number of data points, and $i$ is the number of sections in which the axis deformation was divided.

\subsection{Statistical Analyses}

All experiments were repeated twice based on prior knowledge of the statistical techniques applied and the reliability of the results of the preliminary experiment. The data were statistically 
analyzed using STATISTICA software (Version 13) [54] by employing the ANOVA (San Francisco, CA, USA), correlation, and regression techniques.

\section{Results}

\subsection{Effects of Speed, Temperature, and Relaxation Time on Responses}

The effects of speed, temperature, and relaxation time on deformation, oil yield, oil expression efficiency, and energy of hazelnut kernels are presented in Tables 1-3, respectively. The speed and temperature did not greatly influence the deformation values. The lower speed of $4 \mathrm{~mm} / \mathrm{min}$ combined with a higher temperature of $60^{\circ} \mathrm{C}$ increased the oil expression efficiency by $4.68 \%$. A higher speed rather increased the energy for recovering the kernel oil compared to a higher temperature. This could be attributed to the softening of the kernels and occurrence of the serration effect, which increases the area under the force-deformation curve, which is defined as the energy. Lower speed and higher temperature recorded an equal amount of energy of $0.21 \mathrm{~kJ}$. The relaxation time of $12 \mathrm{~min}$ after compression increased the oil expression efficiency, meaning that the residual kernel oil of $15.6 \%$ was recovered from the kernel cake after compression.

Table 1. Effect of speed on deformation, oil yield, oil expression efficiency, and energy.

\begin{tabular}{ccccc}
\hline * Speed (mm/min) & $\begin{array}{c}\text { Deformation } \\
\mathbf{( m m})\end{array}$ & Oil Yield (\%) & $\begin{array}{c}\text { Oil Expression } \\
\text { Efficiency (\%) }\end{array}$ & Energy (kJ) \\
\hline 4 & $27.75 \pm 2.79$ & $39.76 \pm 0.02$ & $61.48 \pm 0.04$ & $0.21 \pm 0.01$ \\
8 & $27.04 \pm 1.17$ & $37.00 \pm 0.51$ & $57.22 \pm 0.79$ & $0.23 \pm 0.01$ \\
12 & $28.06 \pm 0.74$ & $33.83 \pm 0.88$ & $52.31 \pm 1.37$ & $0.27 \pm 0.04$ \\
\hline \multicolumn{5}{c}{ * Sample compressive force of $60 \mathrm{kN}}$.
\end{tabular}

Table 2. Effect of heating temperature on deformation, oil yield, oil expression efficiency, and energy.

\begin{tabular}{ccccc}
\hline $\begin{array}{c}* \text { Heating } \\
\text { Temperature }\left({ }^{\circ} \mathbf{C}\right)\end{array}$ & $\begin{array}{c}\text { Deformation } \\
(\mathbf{m m})\end{array}$ & Oil Yield (\%) & $\begin{array}{c}\text { Oil Expression } \\
\text { Efficiency (\%) }\end{array}$ & Energy (kJ) \\
\hline 25 & $27.76 \pm 0.24$ & $36.21 \pm 0.04$ & $55.99 \pm 0.06$ & $0.22 \pm 0.001$ \\
40 & $30.61 \pm 0.50$ & $39.83 \pm 0.64$ & $61.59 \pm 0.98$ & $0.20 \pm 0.001$ \\
50 & $30.41 \pm 2.41$ & $42.35 \pm 0.43$ & $65.48 \pm 0.67$ & $0.21 \pm 0.003$ \\
60 & $29.96 \pm 2.11$ & $42.79 \pm 0.24$ & $66.16 \pm 0.37$ & $0.21 \pm 0.001$ \\
\hline
\end{tabular}

* Sample compressive force of $60 \mathrm{kN}$ and speed of $4 \mathrm{~mm} / \mathrm{min}$.

Table 3. Effect of relaxation time on sample heating temperature of $60^{\circ} \mathrm{C}$.

\begin{tabular}{ccc}
\hline$* *$ Relaxation Time (min) & Oil Yield (\%) & Oil Expression Efficiency (\%) \\
\hline 0 & $36.21 \pm 0.04$ & $55.99 \pm 0.06$ \\
3 & $41.73 \pm 0.34$ & $64.53 \pm 0.52$ \\
6 & $45.08 \pm 0.03$ & $69.71 \pm 0.05$ \\
9 & $46.04 \pm 0.96$ & $71.21 \pm 1.48$ \\
12 & $46.31 \pm 0.34$ & $71.59 \pm 0.53$ \\
\hline \multicolumn{2}{c}{$*$ Compressive force of $60 \mathrm{kN}$ and speed of $4 \mathrm{~mm} / \mathrm{min}}$.
\end{tabular}

\subsection{Force-Deformation Curves, Strain, Oil Point Force, and Oil Point Energy}

The force-deformation curves for different speeds and heating temperatures are illustrated in Figures 2 and 3. The strain, oil point force, and oil point energy are also given in Tables 4 and 5 . The maximum applied force of $60 \mathrm{kN}$ was based on a preliminary experiment where a higher force using a pressing vessel diameter of $60 \mathrm{~mm}$ caused a serration effect characterized by the ejection of kernel cake through the holes of the pressing vessel. The strain is the ratio of deformation to the initial height of the sample and is useful for identifying the oil point force with the corresponding energy. 
The lower and upper oil points were observed at deformation values of 20 and $25 \mathrm{~mm}$ at a speed of $4 \mathrm{~mm} / \mathrm{min}$ with the corresponding strain values of 0.5 and $0.625(-)$ for both heat-treated kernels and those without heat treatment. The oil point force and energy of the samples before and after heating were determined from the deformation levels between 15 and $25 \mathrm{~mm}$ (Figure 4). The lower oil point denotes the minimum force required for the first drop of kernel oil whiles the upper oil point describes the maximum force needed to recover maximum kernel oil.

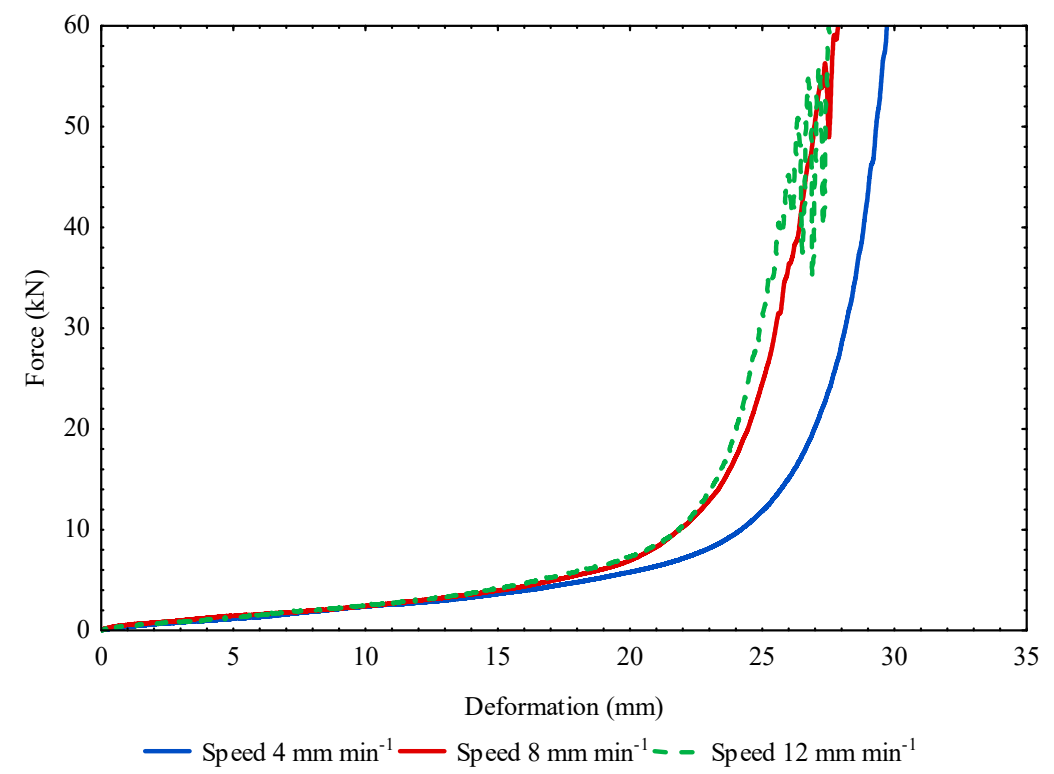

Figure 2. Force-deformation curves of bulk hazelnut kernels for different speeds.

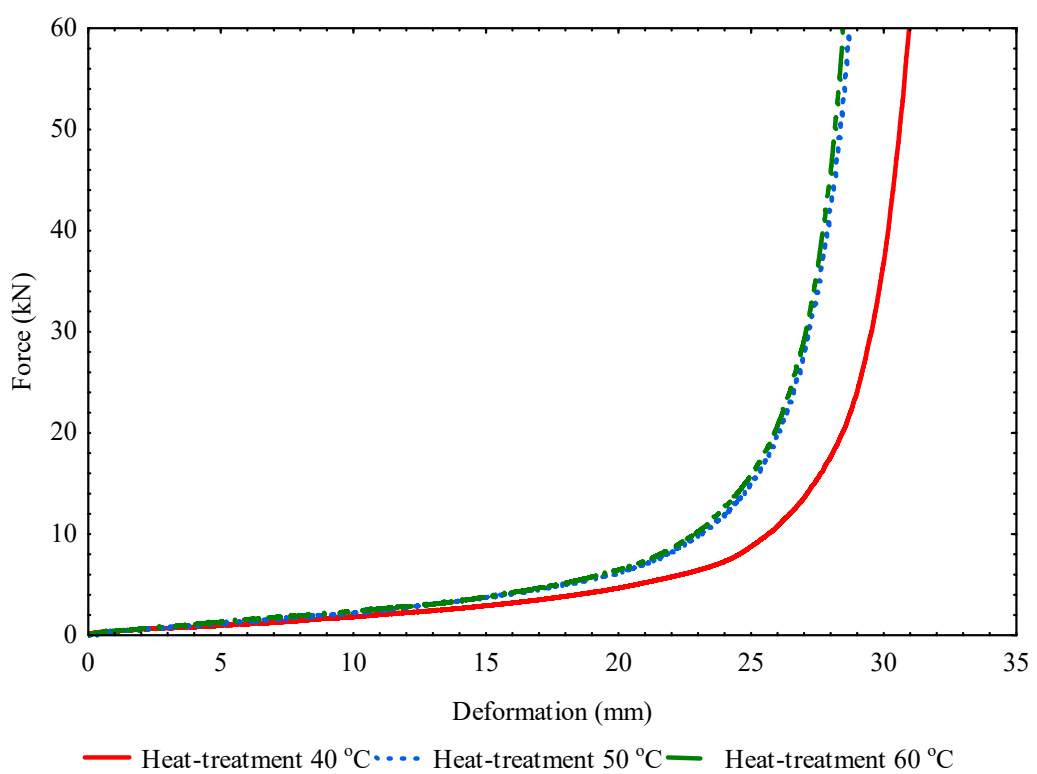

Figure 3. Force-deformation curves of bulk hazelnut kernels for heating temperatures.

Table 4. Strain and oil point force of deformation levels of kernels at a speed of $4 \mathrm{~mm} / \mathrm{min}$.

\begin{tabular}{cccc}
\hline${ }^{*}$ Deformation Levels $(\mathbf{m m})$ & Strain $(-)$ & $* *$ Oil Point Force $(\mathbf{k N})$ & $* *$ Oil Point Energy $(\mathbf{k J})$ \\
\hline 15 & 0.375 & $3.58 \pm 1.13$ & $0.03 \pm 0.01$ \\
20 & $0.5^{\mathrm{a}}$ & $6.46 \pm 0.08$ & $0.06 \pm 0.002$ \\
25 & $0.625^{\mathrm{b}}$ & $10.79 \pm 2.62$ & $0.09 \pm 0.01$ \\
\hline
\end{tabular}

${ }^{*}$ For initial pressing height, $H=40 \mathrm{~mm}$; ${ }^{\text {a }}$ Lower oil point; ${ }^{\mathrm{b}}$ Upper oil point; ${ }^{* *}$ (Control at $25^{\circ} \mathrm{C}$ ). 
Table 5. Strain and oil point force of deformation levels of kernels at a speed of $4 \mathrm{~mm} / \mathrm{min}$.

\begin{tabular}{|c|c|c|c|}
\hline * Deformation Levels (mm) & Strain $(-)$ & *** Oil Point Force $(\mathbf{k N})$ & *** Oil Point Energy (kJ) \\
\hline 15 & 0.375 & $3.22 \pm 0.21$ & $0.02 \pm 0.001$ \\
\hline 20 & $0.5^{\mathrm{a}}$ & $6.21 \pm 0.58$ & $0.05 \pm 0.01$ \\
\hline 25 & $0.625^{b}$ & $10.61 \pm 0.71$ & $0.08 \pm 0.01$ \\
\hline
\end{tabular}

* For initial pressing height, $H=40 \mathrm{~mm} ;{ }^{\text {a }}$ Lower oil point; ${ }^{\mathrm{b}}$ Upper oil point; ${ }^{* * *}$ Heating temperature of $60{ }^{\circ} \mathrm{C}$.

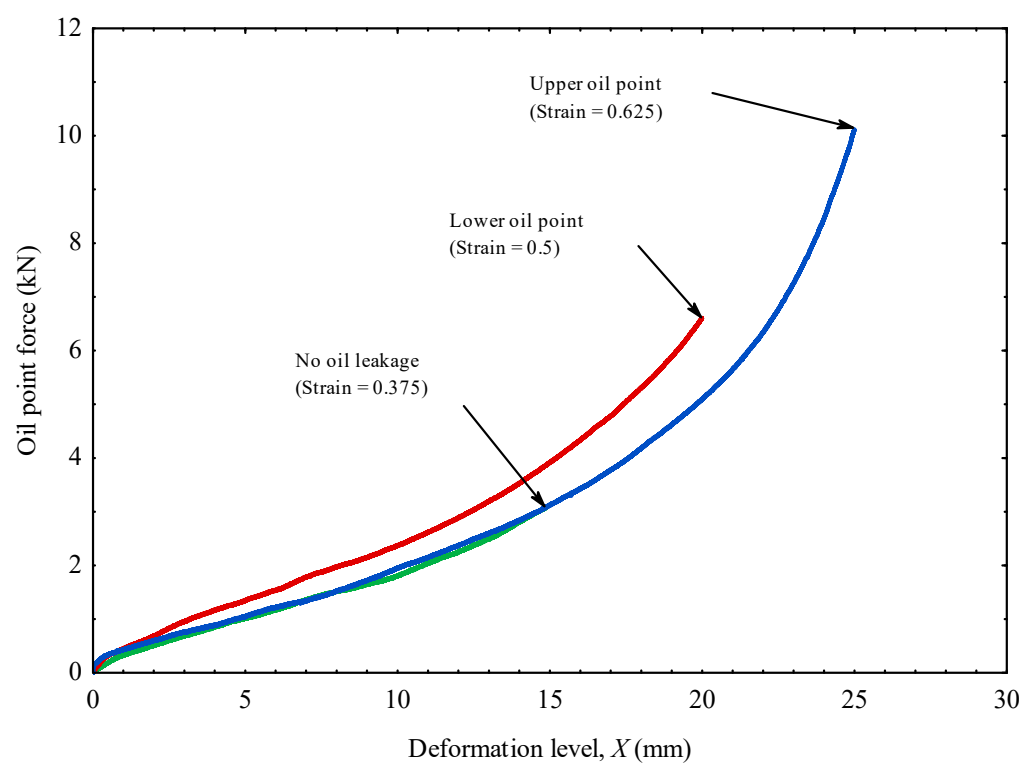

Figure 4. Oil point identification at deformation levels of bulk hazelnut kernels.

\subsection{Peroxide Value and Free Fatty Acid}

In Figure 5 is illustrated the box plot of values for peroxide and free fatty acid of kernel oil at different heating temperatures. The peroxide values of hazelnut kernel oil increased from 40 to $50{ }^{\circ} \mathrm{C}$ and then decreased at $60^{\circ} \mathrm{C}$ but the free fatty acid values decreased linearly with heating temperatures.

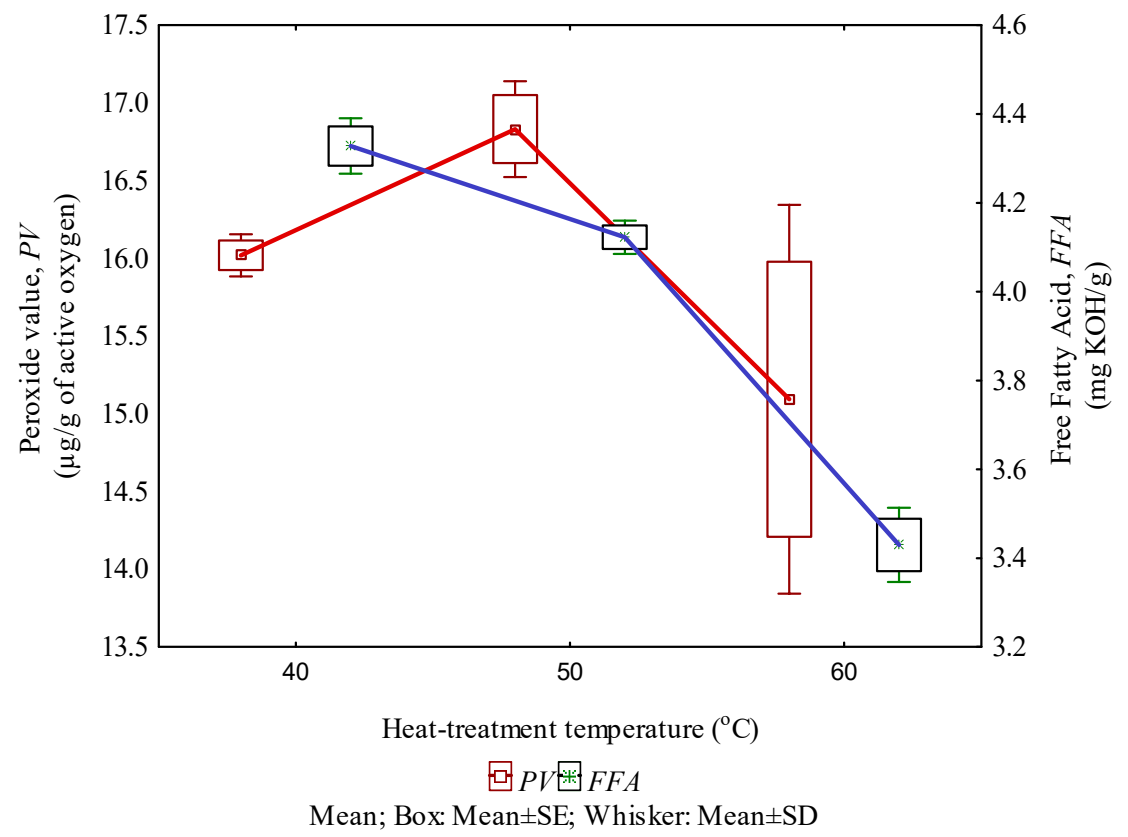

Figure 5. Box plot of peroxide value and free fatty acid of hazelnut kernel oil under heat treatment temperature. 


\subsection{ANOVA, Correlation, and Regression Results}

The results of ANOVA, correlation, and regression of the effects of speed, heating temperature, and relaxation time are given in Tables 6-10. The ANOVA results show that the increase in speed and heating temperature did not significantly $(p>0.05)$ decrease or increase the deformation values of hazelnut kernels. Oil yield and oil expression efficiency significantly $(p<0.05)$ decreased with increased speed while they increased significantly $(p<0.05)$ with heating temperature. The speed and heating temperature combined did not indicate a significant effect $(p>0.05)$ on energy. The correlation results also showed no relationship between deformation and speed as well as deformation and temperature. Oil yield and oil expression efficiency correlated with speed and heating temperature effects with high correlation efficiency between 97 and $99 \%$ respectively. Energy showed no correlation with the effects of speed and heating temperature $(p>0.05)$. The oil point force, oil expression efficiency, and energy were statistically significant $(p<0.05)$ with a coefficient of determination $\left(R^{2}\right)$ of $87 \%$. Peroxide value was not significant $(p>0.05)$ with heating temperature but free fatty acid proved significant $(p<0.05)$ with a correlation efficiency of $95 \%$. The regression equations representing oil yield, oil expression efficiency, and free fatty acid as functions of speed, heating temperature, and relaxation time effects, respectively, indicated significance $(p<0.05)$. The energy and peroxide value against speed and heating temperature revealed a non-significant $(p>0.05)$ effect.

Table 6. ANOVA and correlation results of the effect of speed and heat treatment temperature on the dependent variables.

\begin{tabular}{ccccc}
\hline Dependent Variables & $\mathbf{R}$ & $\mathbf{R}^{2}$ & F-Value & $p$-Value \\
\hline \multirow{2}{*}{ Deformation (mm) } & $0.09^{\mathrm{a}}$ & $0.10^{\mathrm{a}}$ & $0.16^{\mathrm{a}}$ & \\
& $0.49^{\mathrm{b}}$ & $0.49^{\mathrm{b}}$ & $1.29^{\mathrm{b}}$ & $>0.05^{\mathrm{a}, \mathrm{b}}$ \\
Oil yield (\%) & $-0.99^{\mathrm{a}}$ & $0.97^{\mathrm{a}}$ & $50.65^{\mathrm{a}}$ & \\
& $0.89^{\mathrm{b}}$ & $0.99^{\mathrm{b}}$ & $111.89^{\mathrm{b}}$ & $<0.05^{\mathrm{a}, \mathrm{b}}$ \\
Oil expression efficiency (\%) & $-0.99^{\mathrm{a}}$ & $0.97^{\mathrm{a}}$ & $50.65^{\mathrm{a}}$ & \\
& $0.89^{\mathrm{b}}$ & $0.99^{\mathrm{b}}$ & $111.89^{\mathrm{b}}$ & $<0.05^{\mathrm{a}, \mathrm{b}}$ \\
Energy (kJ) & $0.78^{\mathrm{a}}$ & $0.63^{\mathrm{a}}$ & $2.53^{\mathrm{a}}$ & \\
& $0.22^{\mathrm{b}}$ & $0.94^{\mathrm{b}}$ & $19.27^{\mathrm{b}}$ & $>0.05^{\mathrm{a}, \mathrm{b}}$ \\
\hline
\end{tabular}

Compressive force of $60 \mathrm{kN}$ and speed $4 \mathrm{~mm} / \mathrm{min}$; ${ }^{\mathrm{a}}$ Speed; ${ }^{\mathrm{b}}$ heating temperature; Significant $(p$-value $<0.05$ or F-value $>p$-value); Non-significant ( $p$-value $>0.05$ or F-value $<p$-value).

Table 7. ANOVA and correlation results of the effect of relaxation time on oil expression efficiency.

\begin{tabular}{ccccc}
\hline Dependent Variables & $\mathbf{R}$ & $\mathbf{R}^{\mathbf{2}}$ & F-Value & $p$-Value \\
\hline * Oil yield (\%) & 0.91 & 0.99 & \multirow{2}{*}{157.07} & $<0.05$ \\
* Oil expression efficiency (\%) & 0.91 & 0.99 & & \\
\hline
\end{tabular}

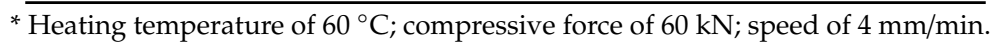

Table 8. ANOVA and correlation results of oil point force, oil expression efficiency and energy.

\begin{tabular}{ccccc}
\hline Dependent Variables & $\mathbf{R}$ & $\mathbf{R}^{\mathbf{2}}$ & F-Value & F-Value \\
\hline & $0.92^{\mathrm{a}}$ & $0.87^{\mathrm{a}}$ & $9.73^{\mathrm{a}}$ & \\
* Oil point force (kN) & $0.99^{\mathrm{b}}$ & $0.98^{\mathrm{b}}$ & $96.03^{\mathrm{b}}$ & \\
* Oil point expression efficiency (\%) & $0.98^{\mathrm{a}}$ & $0.99^{\mathrm{a}}$ & $267.45^{\mathrm{a}}$ & $<0.05^{\mathrm{a}, \mathrm{b}}$ \\
& $0.99^{\mathrm{b}}$ & $0.99^{\mathrm{b}}$ & $1549.86^{\mathrm{b}}$ & \\
* Oil point energy (kJ) & $0.97^{\mathrm{a}}$ & $0.95^{\mathrm{a}}$ & $29.13^{\mathrm{a}}$ & \\
& $0.99^{\mathrm{b}}$ & $0.97^{\mathrm{b}}$ & $56.87^{\mathrm{b}}$ & \\
\hline
\end{tabular}

${ }^{*}$ Speed of $4 \mathrm{~mm} / \mathrm{min} ;{ }^{\text {a }}$ Control at $25^{\circ} \mathrm{C} ;{ }^{\text {b }}$ Heating temperature of $60{ }^{\circ} \mathrm{C}$. 
Table 9. ANOVA and correlation results of $P V$ and $F F A$ in relation to heating temperature.

\begin{tabular}{ccccc}
\hline Dependent variables & $\mathbf{R}$ & $\mathbf{R}^{2}$ & F-Value & $p$-Value \\
\hline $\begin{array}{c}\text { Peroxide value, } P V \\
(\mu \mathrm{g} / \mathrm{g} \text { of active oxygen) }\end{array}$ & -0.43 & 0.64 & 2.70 & $>0.05$ \\
$\begin{array}{c}\text { Free Fatty Acid, } F F A \\
(\mathrm{mg} \mathrm{KOH} / \mathrm{g})\end{array}$ & -0.95 & 0.99 & 108.37 & $<0.05$ \\
\hline
\end{tabular}

Table 10. Regression results of the effects of speed, heating temperature, and relaxation time.

\begin{tabular}{|c|c|c|c|c|}
\hline \multirow{2}{*}{ Dependent Variables } & \multicolumn{4}{|c|}{ Speed, $S_{p}(\mathrm{~mm} / \mathrm{min})$} \\
\hline & Equation & $\mathbf{R}^{2}$ & F-Value & $p$-Value \\
\hline Oil yield (\%) & $42.79-0.74 \times S_{p}$ & 0.97 & 127.60 & $<0.05$ \\
\hline Oil expression efficiency (\%) & $66.17-0.15 \times S_{p}^{r}$ & 0.97 & 127.60 & $<0.05$ \\
\hline Energy (kJ) & $0.18+0.01 \times S_{p}$ & 0.60 & 6.09 & $>0.05$ \\
\hline \multirow{2}{*}{ Dependent variables } & \multicolumn{4}{|c|}{ Heating temperature, $T_{p}\left({ }^{\circ} \mathrm{C}\right)$} \\
\hline & Equation & $\mathbf{R}^{2}$ & F-value & $p$-value \\
\hline Oil yield (\%) & $34.26+0.15 \times T_{p}$ & \multirow{3}{*}{$\begin{array}{l}0.81 \\
0.81\end{array}$} & 16.78 & $<0.05$ \\
\hline Oil expression efficiency (\%) & $52.98+0.23 \times T_{p}$ & & 16.78 & $<0.05$ \\
\hline Energy (kJ) & $0.20+0.0001 \times T_{p}$ & & 0.21 & $>0.05$ \\
\hline \multirow{2}{*}{ Dependent variables } & \multicolumn{4}{|c|}{ Relaxation time $R_{t}$ (min) } \\
\hline & Equation & $\mathbf{R}^{2}$ & F-value & $p$-value \\
\hline Oil yield (\%) & $38.18+0.82 \times R_{t}$ & 0.82 & 37.57 & \multirow{2}{*}{$<0.05$} \\
\hline Oil expression efficiency (\%) & $59.03+1.26 \times R_{t}$ & 0.82 & 37.57 & \\
\hline \multirow{2}{*}{ Dependent variables } & \multicolumn{4}{|c|}{ Heating temperature, $T_{p}\left({ }^{\circ} \mathrm{C}\right)$} \\
\hline & Equation & $\mathbf{R}^{2}$ & F-value & $p$-value \\
\hline $\begin{array}{c}\text { Peroxide value, } P V \\
\text { ( } \mu \mathrm{g} / \mathrm{g} \text { of active oxygen) }\end{array}$ & $18.31-0.05 \times T_{p}$ & 0.18 & 0.89 & $>0.05$ \\
\hline $\begin{array}{l}\text { Free Fatty Acid, FFA } \\
\quad(\mathrm{mg} \mathrm{KOH} / \mathrm{g})\end{array}$ & $6.21-0.04 \times T_{p}$ & 0.91 & 35.27 & $<0.05$ \\
\hline
\end{tabular}

$T_{p}$ : Heating temperature $\left({ }^{\circ} \mathrm{C}\right) ; S_{p}$ : Speed $(\mathrm{mm} / \mathrm{min}) ; R_{t}$ : Relaxation time (min); Significant ( $p$-value $<0.05$ or F-value $>p$-value); Non-significant ( $p$-value $>0.05$ or F-value $<p$-value).

\section{Discussion}

The experimental and statistical results of the effects of speed, heating temperature, and relaxation time on deformation, oil yield, oil expression efficiency, force-deformation curves, peroxide value, and free fatty acid of postharvest processing of hazelnut kernels and oil under uniaxial compression have been described in the preceding sections. The results are herein elaborated.

A lower speed of $4 \mathrm{~mm} / \mathrm{min}$ recovered maximum kernel oil compared to a higher speed of $12 \mathrm{~mm} / \mathrm{min}$, where the minimum oil yield was realized. Increases in speed increased the energy but decreased the oil yield and oil expression efficiency whereas increases in heating temperature showed a significant increase in oil yield and oil expression efficiency but not in energy. Similar results were reported by [55] for jatropha kernels heated at $80^{\circ} \mathrm{C}$. It has been reported that the increase in heat will not always increase the oil yield [56]. The oil yield, however, is dependent on the quality of the oil-bearing material, moisture content, and the oil extraction process. Theoretically, higher screw speed means more seed material throughput and higher oil content residual in the press cake due to less time being available for the oil to discharge from the solids. A lower energy input also means lower oil recovery efficiency, higher oil residue in the press cake, and higher seed material throughput, and higher pressure will lead to higher temperature generation and higher oil recovery efficiency [57-59].

The relaxation time for kernels heated at $60^{\circ} \mathrm{C}$ and compressed at a force of $60 \mathrm{kN}$ and speed of $4 \mathrm{~mm} / \mathrm{min}$ increased the oil yield and oil expression efficiency. A significant increase in oil yield 
and oil expression efficiency occurred at 3 and 6 min of relaxation time in comparison with 9 and $12 \mathrm{~min}$ of the relaxation time. However, the percentage increase of $10.1 \%$ and $15.6 \%$ of oil yield and oil expression efficiency was observed at $12 \mathrm{~min}$ relaxation. The correlation efficiency between oil expression efficiency and relaxation time was $91 \%$. The compression and relaxation processes are important for evaluating the oil yield and energy at the compression area and oil expression efficiency without energy at the relaxation phase, which is dependent on several factors such as the volume of kernels, moisture content, vessel diameter, force, and speed, among other factors [48]. Further, from the principles of viscoelasticity, the relaxation time shows how fast the material dissipates after receiving a sudden deformation, that is, when the maximum force is attained, and it can also be used to characterize the elastic and viscous components in the behavior of the material. The relaxation data can be used to develop rheological models useful in the design of food engineering processes by applying the concepts of momentum, energy, and mass balances [60,61].

The lower oil point force of $6.21 \pm 0.58 \mathrm{kN}$ and the upper oil point force of $10.61 \pm 0.71 \mathrm{kN}$ of hazelnut kernels were observed. Based on these values, a maximum force of $60 \mathrm{kN}$ was applied to recover the maximum kernel oil. However, it was also observed that the oil point forces at both lower and upper oil points for heat-treated kernels were lower compared to kernels without heat treatment. This indicates that kernels without heat treatment are more resistant to breakage and, hence, higher energy than those with heat treatment. The oil point force decreased with increased heating temperature. The results are in agreement with [62] based on cashew kernels. The oil point pressure/force indicates the threshold pressure at which oil emerges from the seed or kernel during mechanical or uniaxial compression [63-65]. The effective pressure for the oil to discharge from oil-bearing cells is determined by first identifying the oil point pressure. The oil point pressure improves the oil expression efficiency and provides useful information for the design and performance evaluation of oil expellers [62,65]. Nevertheless, the oil point force is dependent on the initial moisture content, heat treatment, heating time, speed, vessel diameter, and kernel pressing height and varieties. This suggests that the optimal processing factors for identifying the oil point pressure/force with corresponding energy and for recovering higher percentage kernel oil need to be determined to help in the design of energy-efficient oil processing system.

Peroxide value and free fatty acid of hazelnut kernel oil decreased at the highest heating temperature of $60{ }^{\circ} \mathrm{C}$. This indicates that the quality of the oil at the abovementioned heating temperature might be within the acceptable limit. The explanation is that higher temperature leads to the higher acid value, resulting in high free fatty acid. The lower the acid value, the lower the free fatty acid hence, the better the oil usage quality [55]. Peroxide value and free fatty acid are strongly correlated [66]. Generally, peroxide values in edible oils indicate lipid oxidation whilst free fatty acids indicate lipid hydrolysis [67-69]. Oxidation of edible oils reduces oil quality and human health benefits and, therefore, it is important to minimize lipid oxidation and rancidity [70]. Peroxide values depend on the cultivar, harvest time, delaying of storage after harvest, ecological conditions, cultural management during the growing season, and handling procedures after harvest [71]. On the other hand, enzymatic lipid hydrolysis produces free fatty acids which are driven by a reaction between moisture and oil [72,73].

In addition to the abovementioned facts, mechanical pressing of oil from oil-bearing materials involves the application of pressure by using either a hydraulic or screw press to recover the oil $[52,64]$. Improving the performance of the oil expression process and/or designing an optimum universal pressing system requires understanding of the mechanical and relaxation behaviors of the oil material under uniaxial compression. The results of the present study thus provide supplementary information to the available literature.

\section{Conclusions}

A laboratory-scale study was conducted to examine the mechanical behavior, oil content, and oil efficiency of hazelnut kernels with different speeds, heating temperatures, and relaxation times. 
The quality of the kernel oil was assessed in terms of peroxide value and free fatty acid. The following findings were observed. For a pressing vessel of diameter $60 \mathrm{~mm}$ and sample pressing height of $40 \mathrm{~mm}$, kernel oil efficiency was achieved at a maximum force of $60 \mathrm{kN}$ and speed of $4 \mathrm{~mm} / \mathrm{min}$. The maximum force applied was based on a preliminary experiment, which showed that a greater force under the same processing conditions demonstrated the serration effect, which is not energy efficient for recovering the maximum kernel oil. The lower and upper oil points with strain values of 0.5 and 0.625 with the corresponding forces of $6.21 \pm 0.58$ and $10.61 \pm 0.71 \mathrm{kN}$ were in reference to the maximum force applied for recovering the kernel oil. Peroxide value, $P V$ ( $\mu \mathrm{g} / \mathrm{g}$ of active oxygen), and free fatty acid, FFA (mg KOH/g), of hazelnut kernel oil decreased with heating temperature, indicating that the quality of the oil at $60^{\circ} \mathrm{C}$ is acceptable for use. Regression models representing oil yield, oil expression efficiency, and free fatty acid were described based on the predictors of speed, heat treatment temperature, and relaxation time. The coefficients of the model predictors were statistically significant $(p<0.05)$ for describing the responses. The relaxation time of $12 \mathrm{~min}$ after compression increased the kernel oil expression efficiency of $15.6 \%$, specifying that the compression and relaxation processes for each pressing chamber along the screw configuration need to be considered when designing a screw press to reduce the additional energy for recovering the residual kernel cake oil.

Author Contributions: Conceptualization, G.A.K.G.; A.K.; Č.M. and D.H.; Funding acquisition, D.H.; Methodology, G.A.K.G.; A.K.; Č.M. and A.F.; data curation, A.K.; Č.M.; K.Ç.S. and A.F.; Writing—original draft, G.A.K.G.; A.K. and K.Ç.S.; Writing-review and editing, G.A.K.G.; A.K., K.Ç.S.; Č.M. and D.H. All authors have read and agreed to the published version of the manuscript.

Funding: The research through the project "supporting the development of international mobility of research staff at CULS Prague, was funded by EU, Managing Authority of the Czech Operational Programme Research, Development and Education" Grant Number: CZ.02.2.69/0.0/0.0/16_027/0008366.

Conflicts of Interest: The authors declare no conflict of interest.

\section{References}

1. Guner, M.; Dursun, E.; Dursun, J.G. Mechanical behaviour of hazelnut under compression loading. Biosyst. Eng. 2003, 85, 485-491. [CrossRef]

2. Delprete, C.; Giacosa, S.; Raviola, E.; Rolle, L.; Sesana, R. Experimental characterization and numerical modeling of the compressive mechanical of hazelnut kernels. J. Food Eng. 2015, 166, 364-369. [CrossRef]

3. Young, W.J. A Study of Nuts with Special Reference to Microscopic Identification; U.S. Government Printing Office: Washington, DC, USA, 1912.

4. Demirkaya, E.; Dal, O.; Yuksel, A. Liquefaction of waste hazelnut shell by using sub-and supercritical solvents as a reaction medium. J. Supercrit Fluids. 2019, 150, 11-20. [CrossRef]

5. Baran, Y.; Gokce, H.S.; Durmaz, M. Physical and mechanical properties of cement containing regional hazelnut shell ash wastes. J. Clean. Prod. 2020, 259, 1-9. [CrossRef]

6. FAO. Produccion Avellana. 2016. Available online: http://www.fao.org/faostat/es/\#data/QC/visualize (accessed on 20 July 2020).

7. Lainas, K.; Alasalvar, C.; Bolling, B.W. Effects of roasting on proanthocyanidin contents of Turkish Tombul hazelnut and its skin. J. Funct. Foods. 2016, 23, 647-653. [CrossRef]

8. Perez-Armada, L.; Rivas, S.; Gonzalez, B.; Moure, A. Extraction of phenolic compounds from hazelnut shells by green processes. J. Food Eng. 2019, 255, 1-8. [CrossRef]

9. Ciemniewska-Żytkiewicz, H.; Verardo, V.; Pasini, F.; Bryś, J.; Koczoń, P.; Caboni, M.F. Determination of lipids and phenolic fraction in two hazelnut (Corylus avellana L.) cultivars grown in Poland. Food Chem. 2015, 168, 615-622. [CrossRef] [PubMed]

10. Pelvan, E.; Alasalvar, C.; Uzman, S. Effects of roasting on the antioxidant status and phenolic profiles of commercial turkish hazelnut varieties (Corylus avellana L.). J. Agric. Food Chem. 2012, 60, 1218-1223. [CrossRef] [PubMed]

11. Marzocchi, S.; Pasini, F.; Verardo, V.; Ciemniewska-Zytkiewicz, H.; Caboni, M.F.; Romani, S. Effects of different roasting conditions on physical-chemical properties of Polish hazelnuts (Corylus avellana L. Var. Katalonski). LWT Food Sci. Technol. 2017, 77, 440-448. [CrossRef] 
12. Köksal, A.I.; Artik, N.; Simsek, A.; Günes, N. Nutrient composition of hazelnut (Corylus avellana L.) varieties cultivated in Turkey. Food Chem. 2006, 99, 509-515. [CrossRef]

13. Del Rio, D.; Calani, L.; Dall'Asta, M.; Brighenti, F. Polyphenolic composition of hazelnut skin. J. Agric. Food Chem. 2011, 59, 9935-9941. [CrossRef] [PubMed]

14. Kara, H.; Orem, A.; Yulug, E.; Yucesan, F.B.; Kerimoglu, G.; Yaman, S.O.; Bodur, A.; Turedi, S.; Alasalvar, C. Hazelnut consumption improves testicular antioxidant function and semen quality in young and old male rats. Food Chem. 2019, 294, 1-8. [CrossRef] [PubMed]

15. Yuan, B.; Lu, M.; Eskridge, K.M.; Isom, L.D.; Hanna, A.M. Extraction, identification, and quantification of antioxidant phenolics from hazelnut (Corylus avellana L.) shells. Food Chem. 2018, 244, 7-15. [CrossRef] [PubMed]

16. Shahidi, F.; Alasalvar, C.; Liyana-Pathirana, C.M. Antioxidant phytochemicals in hazelnut kernel (Corylus avellana L.) and hazelnut byproducts. J. Agric. Food Chem. 2007, 55, 1212-1220. [CrossRef] [PubMed]

17. Eskandari, J.; Kermani, A.M.; Kouravand, S.; Zarafshan, P. Design, fabrication, and evaluation a laboratory dry-peeling system for hazelnut using infrared radiation. LWT Food Sci. Technol. 2018, 90, 570-576. [CrossRef]

18. Tas, N.G.; Yilmaz, C.; Gokmen, V. Investigation of serotonin, free and protein-bound tryptophan in Turkish hazelnut varieties and effect of roasting on serotonin content. Food Res. Int. 2019, 120, 865-871. [CrossRef]

19. Alasalvar, C.; Karamac, M.; Kosinska, A.; Rybarczyk, A.; Shahidi, F.; Amarowicz, R. Antioxidant activity of hazelnut skin phenolics. J. Agric. Food Chem. 2009, 57, 4645-4650. [CrossRef]

20. Ozdemir, M.; Seyan, F.G.; Bakan, A.K.; Ilter, S.; Ozay, G.; Devres, O. Analysis of internal browning of roasted hazelnuts. Food Chem. 2001, 73, 191-196. [CrossRef]

21. Burdack-Freitag, A.; Schieberle, P. Changes in the key odorants of Italian hazelnuts (Corylus avellana L. Var. Tonda Romana) induced by roasting. J. Agric. Food Chem. 2010, 58, 6351-6359. [CrossRef]

22. Belviso, S.; Dal Bello, B.; Giacosa, S.; Bertolino, M.; Ghirardello, D.; Giordano, M.; Rolle, L.; Gerbi, V.; Zeppa, G. Chemical, mechanical and sensory monitoring of hot air-and infrared-roasted hazelnuts (Corylus avellana L.) during nine months of storage. Food Chem. 2017, 217, 398-408. [CrossRef]

23. Guler, S.K.; Bostan, S.Z.; Con, A.H. Effects of gamma irradiation on chemical and sensory characteristics of natural hazelnut kernels. Postharvest Biol. Technol. 2017, 123, 12-21. [CrossRef]

24. Ghirardello, D.; Rolle, L.; Zeppa, G. Effects of storage conditions on hazelnut (Corylus avellana L.) textural characteristics. In Proceedings of the VII International Congress of Hazelnuts, Viterbo, Italy, 23 June 2008.

25. Ghirardello, D.; Contessa, C.; Valentini, N.; Zeppa, G.; Rolle, L.; Gerbi, V.; Botta, R. Effect of storage conditions on chemical and physical characteristics of hazelnut (Corylus avellana L.). Postharvest Biol. Technol. 2013, 81, 37-43. [CrossRef]

26. Akinoso, R.; Raji, A.O. Physical properties of fruit, nut and kernel of oil palm. Int. Agrophys. 2011, 25, 1-6.

27. Jahromi, M.K.; Rafiee, S.; Jafari, A.; Bousejin, M.R.G.; Mirasheh, R.; Mohtasebi, S.S. Some physical properties of date fruit (cv. Dairi). Int. Agrophys. 2008, 22, 221-224.

28. Ozturk, I.; Ercisli, S.; Kara, M. Chosen physical properties of olive cultivars (Olea europaea L.). Int. Agrophys. 2009, 23, 309-312.

29. Yurtlu, Y.B.; Yesiloglu, E.; Arslanoglu, F. Physical properties of bay laurel seeds. Int. Agrophys. 2010, 24, 325-328.

30. Ercisli, S.; Ozturk, I.; Kara, M.; Kalkan, F.; Seker, H.; Duyar, O.; Erturk, Y. Physical properties of hazelnuts. Int. Agrophys. 2011, 25, 115-121.

31. Aydin, C. Physical properties of hazelnuts. Biosyst Eng. 2002, 82, 297-303. [CrossRef]

32. Ozdemir, F.; Akinci, I. Physical and nutritional properties of four major commercial Turkish hazelnut varieties. J. Food Eng. 2004, 63, 341-347. [CrossRef]

33. Kibar, H.; Ozturk, T. The effect of moisture content on the physic-mechanical properties of some hazelnut varieties. J. Stored Prod. Res. 2009, 45, 14-18. [CrossRef]

34. Valentini, N.; Rolle, L.; Stevigny, C.; Zeppa, G. Mechanical behaviour of hazelnuts used for table consumption under compression loading. J. Sci Food Agric. 2006, 86, 1257-1262. [CrossRef]

35. Giacosa, S.; Belviso, S.; Bertolino, M.; Bello, B.D.; Gerbi, V.; Ghirardello, D.; Giordano, M.; Zeppa, G.; Rolle, L. Hazelnut kernels (Corylus avellana L.) mechanical and acoustic properties determination: Comparison of test speed, compression or shear axis, roasting, and storage condition effect. J. Food Eng. 2016, 173, 59-68. [CrossRef] 
36. Sirisomboon, P.; Kitchaiya, P.; Pholpho, T.; Mahuttanyavanitch, W. Physical and mechanical properties of Jatropha curcas L. fruits, nuts and kernels. Biosyst. Eng. 2007, 97, 201-207. [CrossRef]

37. Karaj, S.; Muller, J. Determination of physical, mechanical and chemical properties of seeds and kernels of Jatropha curcas L. Ind. Crop. Prod. 2010, 32, 129-138. [CrossRef]

38. Divisova, M.; Herak, D.; Kabutey, A.; Sigalingging, R.; Svatoňová, T. Deformation curve characteristics of rapeseeds and sunflower seeds under compression loading. Sci. Agric. Bohem. 2014, 45, 180-186.

39. Herak, D.; Kabutey, A.; Hrabe, P. Oil point determination of Jatropha curcas L. bulk seeds under compression loading. Biosyst. Eng. 2013, 116, 470-477. [CrossRef]

40. Munson-Mcgee, S.H. D-optimal experimental designs for uniaxial expression. J. Food Process. Eng. 2014, 37, 248-256. [CrossRef]

41. Herak, D.; Kabutey, A.; Choteborsky, R.; Petru, M.; Sigalingging, R. Mathematical models describing the relaxation behaviour of Jatropha curcas L. bulk seeds under axial compression. Biosyst. Eng. 2015, 131, 77-83. [CrossRef]

42. Mizera, C.; Herak, D.; Hrabe, P.; Kabutey, A. Mathematical models describing the creep and stress relaxation behaviour of false banana's fiber (Ensete ventricosum). J. Nat. Fibers. 2019. [CrossRef]

43. Demirbas, A. Oils from Hazelnut Shell and Hazelnut Kernel Husk for Biodiesel Production. Energ. Sournce Part. A 2008, 30, 1870-1875. [CrossRef]

44. ISI. Indian Standard Methods for Analysis of Oilseeds, IS:3579; Indian Standard Institute: New Delhi, India, 1966.

45. Blahovec, J. Agromatereials Study Guide; Czech University of Life Sciences: Prague, Czech Republic, 2008.

46. Niu, L.; Li, J.; Chen, M.-S.; Xu, Z.-F. Determination of oil contents in Sacha inchi (Plukenetia volubilis) seeds at different developmental stages by two methods: Soxhlet extraction and time-domain nuclear magnetic resonance. Ind Crop. Prod. 2014, 56, 187-190. [CrossRef]

47. Danlami, J.M.; Arsad, A.; Zaini, M.A.A. Characterization and process optimization of castor oil (Ricinus communis L.) extracted by the Soxhlet method using polar and non-polar solvents. J. Taiwan Inst. Chem Eng. 2015, 47, 99-104. [CrossRef]

48. Gürdil, G.A.K.; Kabutey, A.; Selvi, K.C.; Hrabě, P.; Herák, D.; Fraňková, A. Investigation of heating and freezing pretreatments on mechanical, chemical and spectral properties of bulk sunflower seeds and oil. Processes 2020, 8, 411. [CrossRef]

49. Chatepa, L.E.C.; Uluko, H.; Masamba, K. Comparison of oil quality extracted from selected conventional and non conventional sources of vegetable oil from Malawi. Afr. J. Biotechnol. 2019, 18, 171-180.

50. Perrier, A.; Delsart, C.; Boussetta, N.; Grimi, N.; Citeau, M.; Vorobiev, E. Effect of ultrasound and green solvents addition on the oil extraction efficiency from rapeseed flakes. Ultrason. Sonochem. 2017, 39, 58-65. [CrossRef]

51. Deli, S.; Masturah, F.; Aris, T.Y.; Nadiah, W.W.A. The effects of physical parameters of the screw press oil expeller on oil yield from Nigella sativa L. Seeds. Int. Food Res. J. 2011, 18, 1367-1373.

52. Demirel, C.; Kabutey, A.; Herak, D.; Gurdil, G.A.K. Comparison of deformation energy of particular oil-bearing crops. In Proceedings of the 58th ICMD, Prague, Czech Republic, 6-8 September 2017; pp. 60-65.

53. Gupta, R.K.; Das, S.K. Fracture resistance of sunflower seed and kernel to compressive loading. J. Food Eng. 2000, 46, 1-8. [CrossRef]

54. StatSoft Inc. (1995). STATISTICA for Windows; StatSoft Inc.: Tulsa, OK, USA, 2013.

55. Sirisomboon, P.; Kitchaiya, P. Physical properties of Jatropha curcas L. kernels after heat treatment. Biosyst. Eng. 2009, 102, 244-250. [CrossRef]

56. Baryeh, E.A. Effect of palm oil processing parameters on yield. J. Food Eng. 2001, 48, 1-6. [CrossRef]

57. Willems, P.; Kuipers, N.J.M.; De Haan, A.B. Hydraulic pressing of oilseeds: Experimental determination and modeling of yield and pressing rates. J. Food Eng. 2008, 89, 8-16. [CrossRef]

58. Willems, P.; Kuipers, N.J.M.; De Haan, A.B. A consolidation based extruder model to explore GAME process configurations. J. Food Eng. 2009, 90, 238-245. [CrossRef]

59. Karaj, S.; Muller, J. Optimizing mechanical oil extraction of Jatropha curcas L. seeds with respect to press capacity, oil recovery and energy efficiency. Ind Crop. Prod. 2011, 34, 1010-1016. [CrossRef]

60. Sahin, S.; Gulum, S. Physical Properties of Foods; Middle East Technical University: Ankara, Turkey, 2006.

61. Chakespari, A.G.; Rajabipour, A.; Mobli, H. Anisotropic relaxation and creep properties of apple (cv. Shafi Abadi and Golab Kohanz). Adv. J. Food Sci Technol. 2010, 2, 200-205. 
62. Ogunsina, B.S.; Owolarafe, O.K.; Olatunde, G.A. Oil point pressure of cashew (Anacardium occidentale) kernels. Int. Agrophys. 2008, 22, 53-59.

63. Faborade, M.O.; Favier, J.F. Identification and significance of the oil-point in seed-oil expression. J. Agric. Res. 1996, 65, 335-345. [CrossRef]

64. Ajibola, O.O.; Okunade, D.A.; Owolarafe, O.K. Oil point pressure of soybean. J. Food Process. Eng. 2002, 25, 407-416. [CrossRef]

65. Mrema, G.C.; McNulty, P.B. Mathematical model of mechanical oil expression from oilseeds. J. Agric. Eng. Res. 1985, 31, 361-370. [CrossRef]

66. Christopoulos, M.V.; Tsantili, E. Oil composition in stored walnut cultivars-Quality and nutritional value. Eur. J. Lipid Sci. Technol. 2015, 117, 338-348. [CrossRef]

67. Maskan, M.; Karataş, Ş. Fatty acid oxidation of pistachio nuts stored under various atmospheric conditions and different temperatures. J. Sci. Food Agric. 1998, 77, 334-340. [CrossRef]

68. Buransompob, A.; Tang, J.; Mao, R.; Swanson, B.G. Rancidity of walnuts and almonds affected by short time heat treatments for insect control. J. Food Process. Preserv. 2003, 27, 445-464. [CrossRef]

69. Gecgel, U.; Gumus, T.; Tasan, M.; Daglioglu, O.; Arici, M. Determination of fatty acid composition of $\gamma$-irradiated hazelnuts, walnuts, almonds, and pistachios. Radiat. Phys. Chem. 2011, 80, 578-581. [CrossRef]

70. Shahidi, F.; Zhong, Y. Lipid oxidation and improving the oxidative stability. Chem. Soc. Rev. 2010, 39, 4067-4079. [CrossRef] [PubMed]

71. Gama, T.; Wallace, H.M.; Trueman, S.J.; Hosseini-Bai, S. Quality and shelf life of tree nuts: A review. Sci. Hortic. 2018, 242, 116-126. [CrossRef]

72. Phatanayindee, S.; Borompichaichartkul, C.; Srzednicki, G.; Craske, J.; Wootton, M. Changes of chemical and physical quality attributes of macadamia nuts during hybrid drying and processing. Dry. Technol. 2012, 30, 1870-1880. [CrossRef]

73. Ling, B.; Hou, L.; Li, R.; Wang, S. Thermal treatment and storage condition effects on walnut paste quality associated with enzyme inactivation. Food Sci. Technol. 2014, 59, 786-793. [CrossRef]

(C) 2020 by the authors. Licensee MDPI, Basel, Switzerland. This article is an open access article distributed under the terms and conditions of the Creative Commons Attribution (CC BY) license (http://creativecommons.org/licenses/by/4.0/). 